\title{
ENERGY REQUIREMENTS OF USING OIL SHALE IN THE PRODUCTION OF ORDINARY PORTLAND CLINKER
}

\author{
H. ALLABOUN, A. Y. AL-OTOOM* \\ Department of Chemical Engineering \\ Jordan University of Science and Technology \\ P.O. Box 3030, 22110 Irbid, Jordan
}

\begin{abstract}
Energy balance was performed on the clinkering process when utilizing oil shale as a source of both raw materials and energy. The balance was also compared with the typical energy requirements for production of Ordinary Portland (OP) Clinker. The use of Jordanian oil shale can reduce energy requirements in production of OP clinker by 15-20\%. This reduction is due to two factors: lower clinkering temperature of $1300-1350{ }^{\circ} \mathrm{C}$ and an appropriate proportion of the proposed raw materials. An additional energy of $1726 \mathrm{~kJ} / \mathrm{ton}$ clinker, which represents $45 \%$ of the required energy, is needed to achieve the required clinkering temperature. This could be achieved by estimating the amounts of makeup fuel basing on the net calorific value of this fuel.
\end{abstract}

\section{Introduction}

Cement industry is known to consume a large share of the total industrial use of energy and it is estimated at $30-40 \%$ in some countries [1]. Different sources of energy have been utilized either in the form of electrical power or in the form of thermal energy. The amount of energy consumed in the production of OP clinker ranged from 3000 to $6000 \mathrm{~kJ} / \mathrm{kg}$ clinker depending on the type of process and raw materials [2].

Coal, heavy oil, and natural gas are used as thermal energy resources for production of cement clinker. Other fuels like oil shale and biomass may also be used. Although oil shale is considered one of the largest potential energy resources in the world, its use in the production of clinker is still limited.

Soaring prices of oil have led many investors to consider oil-alternative energy resources. The oil equivalent of oil shale around the world is estimated to be about 30 times the reserve of crude oil [3]. Jordan possesses

\footnotetext{
*Corresponding author: e-mail awni_otoom@just.edu.jo
} 
large oil shale deposits, which are located in several areas mainly in ElLajjun, Sultani, Jurf Eddarawish, Wadi Mgher, and Khan Ez-Zabib.

Commercialization of oil shale in the form of oil is being studied. The high percentage of ash in the Jordanian oil shale (50-60\%) makes the future of utilization of oil shale as a source of liquid fuel uncertain [4]. Cementing properties of oil shale on its own have been found earlier to be poor [5]. A recent study has been completed to study the thermodynamics of proportioning oil shale with other cement raw materials [6]. The study showed that oil shale ash can be used with the following proportions; $16 \%$ oil shale ash, $18 \%$ clay, mainly kaolinite, and $66 \%$ calcite. The study also confirmed that a lower clinkering temperature $\left(1300-1350{ }^{\circ} \mathrm{C}\right)$ is required to produce OP clinker. This in part is capable of reducing the amount of energy and thus the cost of producing OP clinker.

This work is a part of an ongoing research on utilization of the Jordanian oil shale in the production of OP clinker. The study aims to find the energy requirements for the above mentioned blending ratio. It also aims to find the amount of additional heat required in addition to the heat generated from combustion of oil shale.

\section{Methodology}

\section{Production of OP clinker}

\section{Material balance}

Material balance is performed initially on production process of OP clinker using the typical chemical composition of minerals in OP clinker: (mass \%) $\mathrm{C}_{3} \mathrm{~S}-45 ; \mathrm{C}_{2} \mathrm{~S}-25 ; \mathrm{C}_{3} \mathrm{~A}-22 ; \mathrm{C}_{4} \mathrm{AF}-8$. From these proportions the amount of $\mathrm{CaO}$ and hence the amount of $\mathrm{CaCO}_{3}$ are determined. Using a similar methodology, the amounts of kaolinite, and silica were calculated. A full description of this methodology is explained below [7]:

$$
\begin{gathered}
\text { Total moles of } \mathrm{CaO} \text { required }=3 \text { moles of } C_{3} S+2 \text { moles of } C_{2} S \\
+3 \text { moles of } C_{3} A+4 \text { moles of } C_{4} A F
\end{gathered}
$$

Total moles of $\mathrm{CaCO}_{3}$ required $=$ total moles of $\mathrm{CaO}$

Total moles of $\mathrm{Fe}_{2} \mathrm{O}_{3}$ required $=$ moles of $\mathrm{C}_{4} \mathrm{AF}$

Total moles of $\mathrm{Al}_{2} \mathrm{O}_{3}=$ moles of $\mathrm{C}_{4} \mathrm{AF}+$ moles of $\mathrm{C}_{3} \mathrm{~A}$

Moles of kaolinite required $=$ total moles of $\mathrm{Al}_{2} \mathrm{O}_{3}$

Moles of free $\mathrm{SiO}_{2}$ required $=$ moles of $\mathrm{C}_{3} \mathrm{~S}+$ moles of $\mathrm{C}_{2} \mathrm{~S}$ -2 moles of kaolinite,

where

$\mathrm{C}_{3} \mathrm{~S}$ tricalcium silicate $\left(3 \mathrm{CaO} \cdot \mathrm{SiO}_{2}\right)$

$\mathrm{C}_{2} \mathrm{~S}$ dicalcium silicate $\left(2 \mathrm{CaO} \cdot \mathrm{SiO}_{2}\right)$ 
$\mathrm{C}_{3} \mathrm{~A} \quad$ tricalcium aluminate $\left(3 \mathrm{CaO} \cdot \mathrm{Al}_{2} \mathrm{O}_{3}\right)$

$\mathrm{C}_{4} \mathrm{AF}$ tetracalcium aluminoferrite $\left(4 \mathrm{CaO} \cdot \mathrm{Al}_{2} \mathrm{O}_{3} \cdot \mathrm{Fe}_{2} \mathrm{O}_{3}\right)$

\section{Energy balance}

Energy balance was performed utilizing the calculated amounts of $\mathrm{CaCO}_{3}$, clay, and kaolinite in the raw materials. All processes in the production of clinker are divided into hypothetical paths as shown in Fig. 1. All of these hypothetical paths are considered basing on the main transformations that happen to the OP raw materials [7]. On a basis of 1 ton of OP clinker produced at $1450{ }^{\circ} \mathrm{C}$, the amount of required energy has been calculated by adding all enthalpies of all hypothetical paths drawn:

$$
Q=\sum^{\text {Paths }} M \cdot \Delta H_{\text {Sens }}+\sum^{\text {Paths }} N \cdot \Delta H_{r x n}+\sum^{\text {Paths }} N \cdot \Delta H_{m},
$$

where $M$ is the mass of component $(\mathrm{kg})$, and $N$ is mole of component.

The sensible heat $\left(\Delta H_{\text {sens }}^{*}\right)$ of all species is calculated using

$$
\Delta H_{\text {Sens }}=M \int_{T 1}^{T 2} c p d T
$$

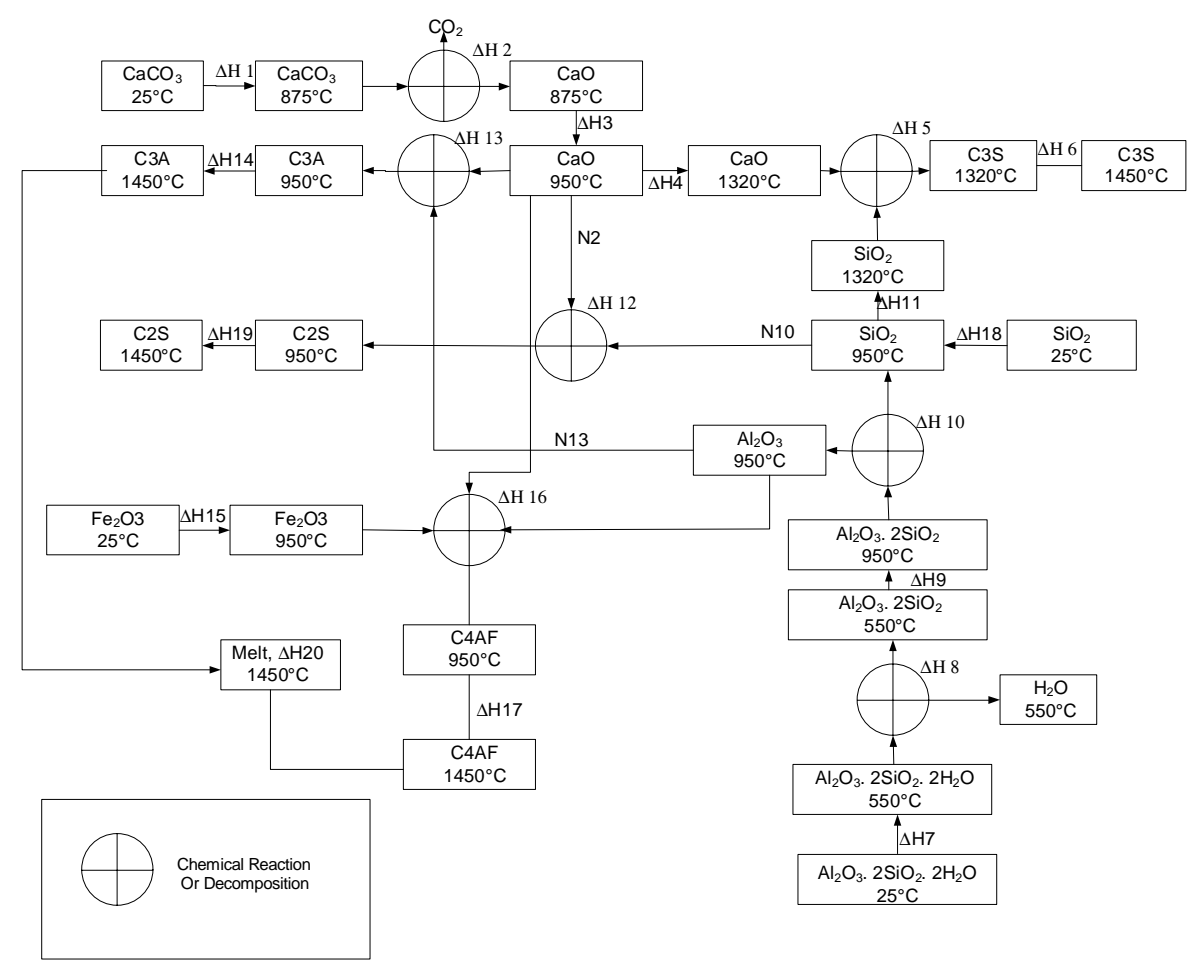

Fig. 1. Schematic diagram of hypothetical paths in OP clinker production. 
The heat of reaction $\left(\Delta H_{\mathrm{rxn}}^{*}\right)$ was calculated from the difference between the heat for formation of the products and the reactants:

$$
\Delta H_{r x n}^{*}=\sum_{\text {products }} \Delta H_{f}^{*}-\sum_{\text {reactants }} \Delta H_{f}^{*} .
$$

The thermodynamic data used in this study are summarized in Table 1 and Table 2.

The heat of melting and the proportions of melt were found using the software of Facility for the Analysis of Chemical Thermodynamics (FACT). A full description of the above mentioned software is described elsewhere $[8,9]$. The heat of melting obtained by FACT was compared with the values given in the literature and found to be approximately $44 \mathrm{~kJ} / \mathrm{mol}$ of melt [7].

Table 1.Thermodynamic data for raw materials and clinker compounds

\begin{tabular}{|l|c|l|}
\hline \multicolumn{1}{|c|}{ Compound } & $\begin{array}{c}\text { Heat of formation, } \\
\Delta \mathrm{H}_{\mathrm{f}}^{\mathrm{o}}, \mathrm{kJ} / \mathrm{mol} \\
{[11-13]}\end{array}$ & \multicolumn{1}{c|}{$\mathrm{Cp}, \mathrm{kJ} / \mathrm{kg} \cdot \mathrm{K}$} \\
& -1207 & $1.04+2.19 \times 10^{-4} \mathrm{~T}-2.6 \times 10^{-2} \mathrm{~T}^{-2}$ \\
$\mathrm{CaCO}_{3}$ & -635 & $0.886+1.01 \times 10^{-4} \mathrm{~T}-1.1 \times 10^{-8} \mathrm{~T}^{2}$ \\
$\mathrm{CaO}$ & -822 & $0.954-8.02 \times 10^{-5} \mathrm{~T}+3.72 \times 10^{-8} \mathrm{~T}^{2}$ \\
$\mathrm{Fe}_{2} \mathrm{O}_{3}$ & -908 & $1.21+2.16 \times 10^{-5} \mathrm{~T}-6.89 \times 10^{4} \mathrm{~T}^{-2}$ \\
$\mathrm{SiO}_{2}$ & -1669 & $1.13+1.52 \times 10^{-4} \mathrm{~T}-2.02 \times 10^{-8} \mathrm{~T}^{2}$ \\
$\mathrm{Al}_{2} \mathrm{O}_{3}$ & -393 & $0.82+9.62 \times 10^{-4} \mathrm{~T}-6.56 \times 10^{-7} \mathrm{~T}^{2}$ \\
$\mathrm{CO}_{2}$ & -4120 & $1.105+8.38 \times 10^{-4} \mathrm{~T}-4.3 \times 10^{-7} \mathrm{~T}^{2}$ \\
$\mathrm{Al}_{2} \mathrm{O}_{3} \cdot 2 \mathrm{SiO}_{2} \cdot 2 \mathrm{H}_{2} \mathrm{O}$ & -2578 & $1.19+6.3 \times 10^{-5} \mathrm{~T}-6.68 \times 10^{-9} \mathrm{~T}^{2}$ \\
$\mathrm{Al}_{2} \mathrm{O}_{3} \cdot 2 \mathrm{SiO}_{2}$ & -241 & $1.85+3.8210^{-4} \mathrm{~T}+4.22 \times 10^{-7} \mathrm{~T}^{2}$ \\
$\mathrm{H}_{2} \mathrm{O}(\mathrm{g})$ & -2308 & $0.784+2.68 \times 10^{-4} \mathrm{~T}$ \\
$\mathrm{C}_{2} \mathrm{~S}$ & -2931 & $0.916+1.58 \times 10^{-4} \mathrm{~T}-1.87 \times 10^{4} \mathrm{~T}^{-2}$ \\
$\mathrm{C}_{3} \mathrm{~S}$ & -3561 & $0.930+4.88 \times 10^{-4} \mathrm{~T}-7.68 \times 10^{4} \mathrm{~T}^{-2}$ \\
$\mathrm{C}_{3} \mathrm{~A}$ & -5080 & $3.25+1.504 \times 10^{-4} \mathrm{~T}-7.52 \times 10^{2} \mathrm{~T}^{-2}$ \\
$\mathrm{C}_{4} \mathrm{AF}$ & \multicolumn{2}{|}{} \\
\hline
\end{tabular}

Table 2. Reactions and decomposition processes occurring at clinker production

\begin{tabular}{|l|r|c|}
\hline \multicolumn{1}{|c|}{ Reaction } & $\mathrm{T},{ }^{\circ} \mathrm{C}$ & $\begin{array}{c}\Delta \mathrm{H}_{\mathrm{rxn}}, \\
\mathrm{kJ} / \mathrm{mol}\end{array}$ \\
\hline $\mathrm{CaCO}_{3} \rightarrow \mathrm{CaO}+\mathrm{CO}_{2}$ & 875 & 16 \\
$3 \mathrm{CaO}+\mathrm{SiO}_{2} \rightarrow \mathrm{C}_{3} \mathrm{~S}$ & 1300 & -173 \\
$\mathrm{Al}_{2} \mathrm{O}_{3} \cdot 2 \mathrm{SiO}_{2} \cdot 2 \mathrm{H}_{2} \mathrm{O} \rightarrow \mathrm{Al}_{2} \mathrm{O}_{3} \cdot 2 \mathrm{SiO}_{2}+2 \mathrm{H}_{2} \mathrm{O}$ & 550 & 1049 \\
$\mathrm{Al}_{2} \mathrm{O}_{3} \cdot 2 \mathrm{SiO}_{2} \rightarrow \mathrm{Al}_{2} \mathrm{O}_{3}+2 \mathrm{SiO}_{2}$ & 950 & -784 \\
$2 \mathrm{CaO}+\mathrm{SiO}_{2} \rightarrow \mathrm{C}_{2} \mathrm{~S}$ & 950 & -186 \\
$4 \mathrm{CaO}+\mathrm{Fe}_{2} \mathrm{O}_{3}+\mathrm{Al}_{2} \mathrm{O}_{3} \rightarrow \mathrm{C}_{4} \mathrm{AF}$ & 950 & -19 \\
\hline
\end{tabular}




\section{Production of OP clinker with oil shale}

\section{Material balance}

Material balance is performed when utilizing the ratios of blending $16 \%$ oil shale ash, $16 \%$ kaolinite, and $66 \%$ calcite. The amounts of $\mathrm{C}_{3} \mathrm{~S}, \mathrm{C}_{2} \mathrm{~S}, \mathrm{C}_{3} \mathrm{~A}$, and $\mathrm{C}_{4} \mathrm{AF}$ have been calculated and compared with the amounts found by FACT in the previous study. The proportions of the above compounds obtained by FACT are shown in Fig. 2.

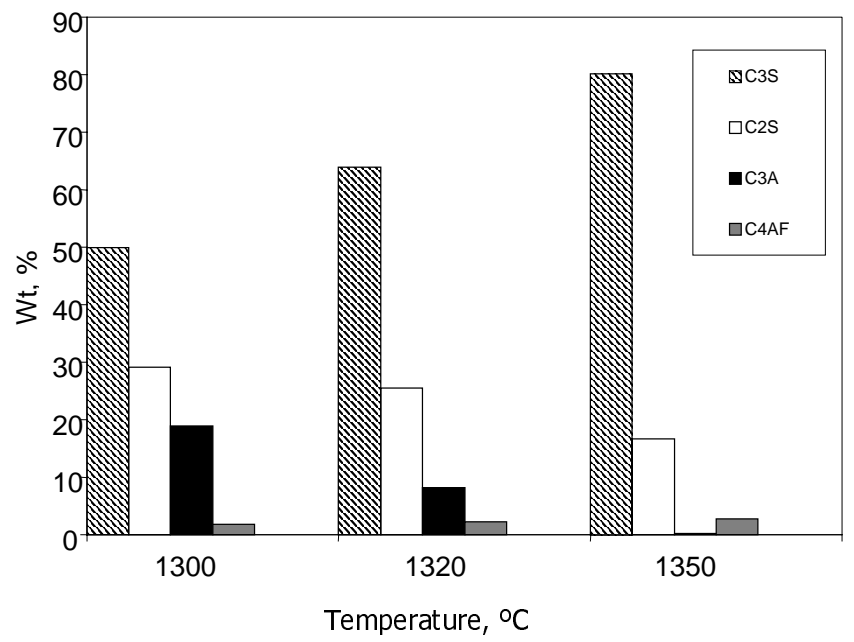

Fig. 2. Proportions of clinker compounds when utilising oil shale as OP raw material [6].

\section{Energy balance}

Energy balance was performed using a method similar to that described above. However, since the maximum temperature is $1300-1350{ }^{\circ} \mathrm{C}$, the hypothetical paths are slightly different from the above paths and shown in Fig. 3.

\section{Results and discussion}

\section{Material and energy balance for OP clinker}

Based on typical values of clinker mineral composition given above, raw materials that constitute this clinker have been calculated by stoichiometric proportioning. The raw materials required for 100 gram clinker $(\mathrm{g} / 100 \mathrm{~g}$ clinker): $\mathrm{CaCO}_{3}-119.3 ; \mathrm{Al}_{2} \mathrm{O}_{3} \cdot 2 \mathrm{SiO}_{2} \cdot 2 \mathrm{H}_{2} \mathrm{O}-25.26 ; \mathrm{SiO}_{2}-17.62 ; \mathrm{Fe}_{2} \mathrm{O}_{3}-$ 2.63 , total -164.8 . It is noted that the total mass of the raw material is greater than the mass of the final product since decomposition reactions of $\mathrm{CaCO}_{3}$ and $\mathrm{Al}_{2} \mathrm{O}_{3} \cdot 2 \mathrm{SiO}_{2} \cdot 2 \mathrm{H}_{2} \mathrm{O}$ release $\mathrm{CO}_{2}$ and $\mathrm{H}_{2} \mathrm{O}$, respectively, into the gaseous phase. Therefore, the remaining solids shall add up to 100 grams of clinker. 
Energy balance on transformation of raw materials in typical proportions of clinker is explained in Fig. 1. This figure is based on dividing these transformations into small and simpler hypothetical paths in series and in parallel in order to account for all reactions and heating processes during the production of clinker. The heat of reaction has been calculated from the difference between the heat of formation of the products and that of the reactants at reaction temperatures. A summary of the heats of reactions involved in the production of clinker is also given in Table 2.

The value resulted from adding up the summation of all the heats of the hypothetical paths is approximately $4100 \mathrm{~kJ} /$ ton clinker. This value is within the average value for the heat requirement for the production of Portland clinker [2].

\section{Material and energy balance for using oil shale to produce OP clinker}

Previous study on thermodynamics suggested that the use of $16 \%$ oil shale ash, $18 \%$ kaolinite, and $66 \%$ calcite would produce similar proportions of OP clinker [6]. The composition of oil shale mineral matter is as follows (wt.\%): $\mathrm{CaCO}_{3}-38.1 ; \mathrm{Al}_{2} \mathrm{O}_{3} \cdot 2 \mathrm{SiO}_{2} \cdot 2 \mathrm{H}_{2} \mathrm{O}-17.5 ; \mathrm{SiO}_{2}-23 ; \mathrm{CaSO}_{4}-15.9$; $\mathrm{Fe}_{2} \mathrm{O}_{3}-3.1$, while final composition of the proposed raw materials blend with this oil shale is (mass $\mathrm{g}$ per $100 \mathrm{~g}$ clinker): $\mathrm{CaCO}_{3}-128.7$; $\mathrm{Al}_{2} \mathrm{O}_{3} \cdot 2 \mathrm{SiO}_{2} \cdot 2 \mathrm{H}_{2} \mathrm{O}-24.2 ; \quad \mathrm{SiO}_{2}-3.7 ; \mathrm{CaSO}_{4}-2.5 ; \quad \mathrm{Fe}_{2} \mathrm{O}_{3}-0.5 ;$ total 159.6. These proportions were found to be produced at temperatures starting from $1300{ }^{\circ} \mathrm{C}$. This temperature is $150{ }^{\circ} \mathrm{C}$ less than normal operating temperature of OP clinker. Figure 2 shows these proportions at different temperatures.

Material balance calculations started from the above suggested proportions to find all intermediate and final compositions of OP clinker. The composition of final clinker (mass $\%, \mathrm{C}_{3} \mathrm{~S}-53 ; \mathrm{C}_{2} \mathrm{~S}-25 ; \mathrm{C}_{3} \mathrm{~A}-19$; $\mathrm{C}_{4} \mathrm{AF}-3$ ) is within normal specifications of OP clinker and similar to that obtained in the previous study as shown in Fig. 2 [6].

Energy balance calculations were performed using a method similar to that mentioned before. Figure 3 shows the steps of the hypothetical paths when utilizing oil shale. This procedure was repeated at final temperatures of $1320,1335,1350$, and $1450{ }^{\circ} \mathrm{C}$ in order to compare the energy requirements when using Jordanian oil shale in the production of clinker.

Operating at the suggested temperatures found in previous studies (1300$1350{ }^{\circ} \mathrm{C}[6]$ ) has shown an energy saving of around $15-20 \%$, as shown in Fig. 4, which reflects great savings in the energy cost. This reduction of energy is believed to occur as a result of formation of low eutectic temperatures when using oil shale. The initial composition of clinker raw material differs when using oil shale. This composition slightly differs from normal composition of OPC. Energy requirements when using oil shale with the determined blend at the same operating temperature as the typical clinker production temperature $\left(1450^{\circ} \mathrm{C}\right)$ has also resulted in energy saving by approximately $15 \%$. This reflects that the energy saving does not only come 
from reducing the operating temperature, but it also comes from the optimized raw material blend when using oil shale.

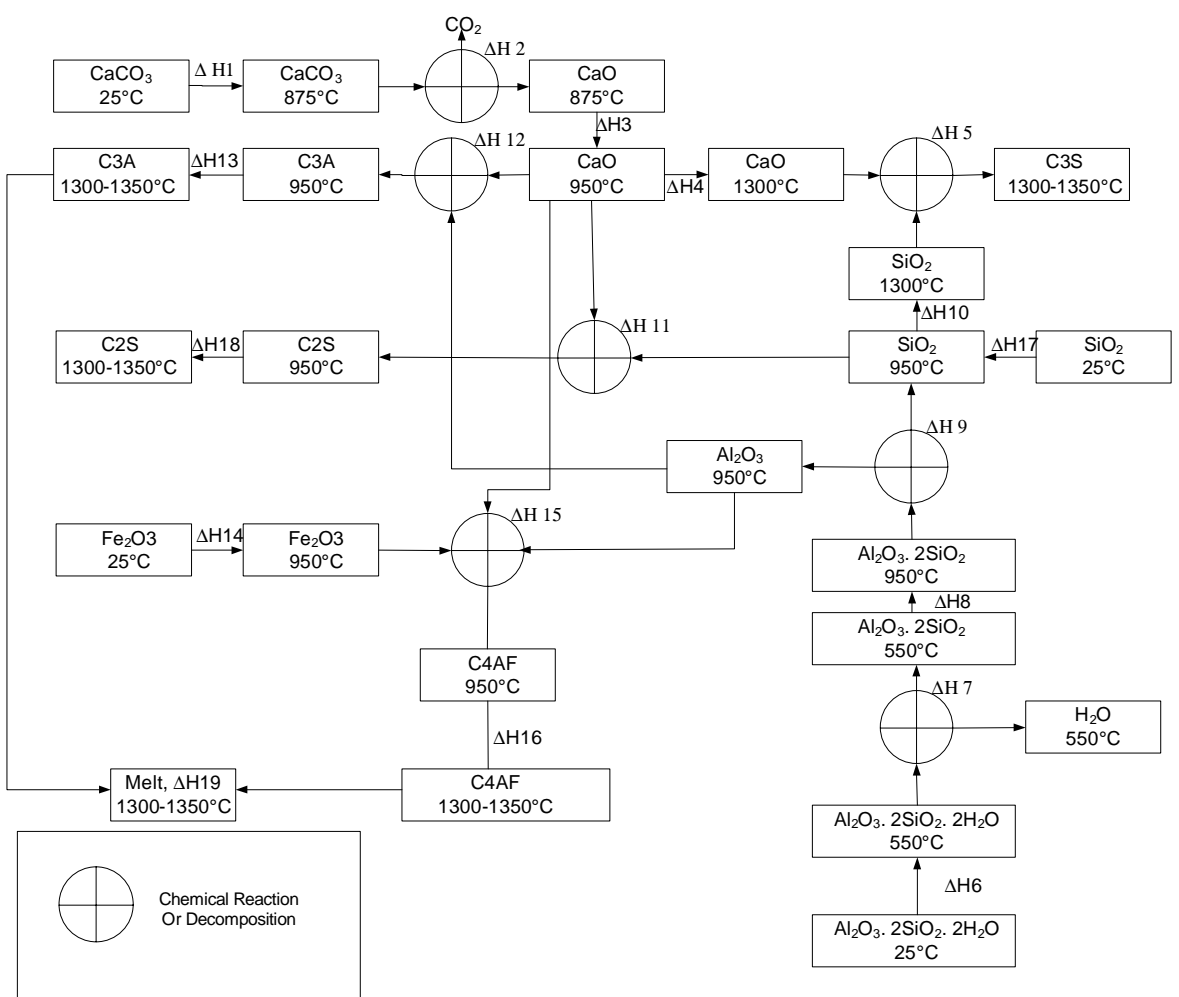

Fig. 3. Schematic diagram of hypothetical paths in OP clinker production when utilizing oil shale.

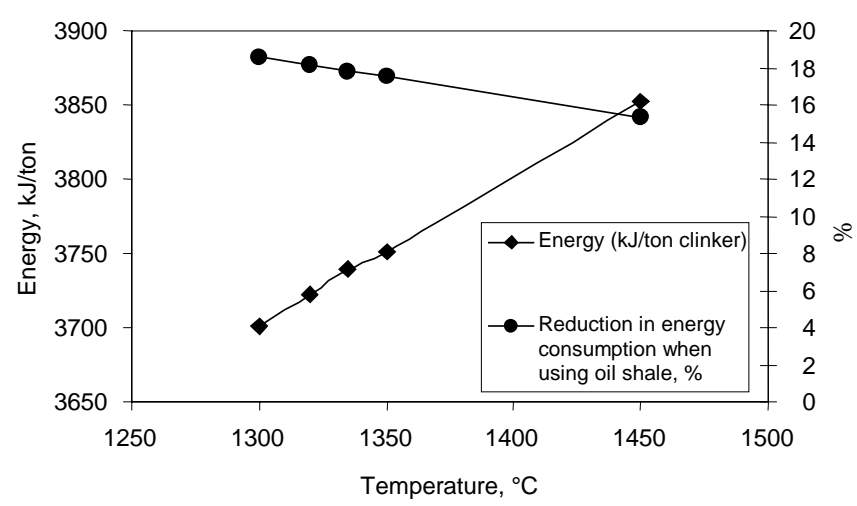

Fig. 4. Energy requirements and reduction in energy use when utilizing oil shale in the production of OP clinker. 
One of the largest deposits of oil shale in Jordan is the El-Lajjun deposit. Ash content of this oil shale is $54 \%$. Therefore, when using $16 \%$ oil shale ash in the raw material blend, this corresponds to using $296 \mathrm{~kg}$ of oil shale per ton of clinker. Since the calorific value of El-Lajjun oil shale is $6906 \mathrm{~kJ} / \mathrm{kg}$ [10], the amount of energy that can be used is $2044 \mathrm{~kJ} / \mathrm{ton}$ of clinker. The average heat requirements for clinkering blends with oil shale at $1300-1350{ }^{\circ} \mathrm{C}$ are $3770 \mathrm{~kJ} / \mathrm{kg}$, therefore, additional heat of $1726 \mathrm{~kJ} / \mathrm{kg}$ or $45 \%$ additional energy is needed.

\section{Conclusions}

This work is a part of an ongoing work to determine energy requirements for production of OP clinker when utilizing local oil shale. This was achieved by performing energy balance on the clinkering process by dividing all processes into hypothetical paths and the changes in enthalpy were calculated for each of these paths.

When utilizing oil shale in the proposed blend (16\% oil shale ash, $18 \%$ kaolinite, and $66 \% \mathrm{CaCO}_{3}$ ), there would be an energy savings of $15-20 \%$ owing to the nature of the raw materials used and low clinkering temperatures required $\left(1300-1350{ }^{\circ} \mathrm{C}\right)$. This low temperature can be achieved since the eutectic temperature of the proposed blend with oil shale is low. The formation of a significant amount of liquid phase during clinkering is extremely important. This significant amount can only be achieved at temperatures higher than $1400{ }^{\circ} \mathrm{C}$ in a typical OP clinker. While, when using oil shale, a significant amount of liquid has been achieved at temperatures of $1300-1350{ }^{\circ} \mathrm{C}[6]$.

The composition of the resulting clinker when using oil shale in the blend is slightly different from the average composition of the OPC. Although the final properties of the cement would slightly differ from the average composition of OP clincker, the new composition ratios obtained when using oil shale are within acceptable limits of OP clinker.

\section{REFERENCES}

1. Szabo, L., Hidalgo, I., Ciscar, J. C., Soria, A., Russ, P. Energy consumption and $\mathrm{CO}_{2}$ emissions from the world cement industry. - European Commission Joint Research Centre, Report EUR 20769 EN, June 2003.

2. European Cement Association. cement \& lime bref revision cembureau contribution specific energy consumption. 2006, Report No. T6318/CL/OMR/MHT.

3. Russell, P. L. Oil Shales of the World; Their Origin Occurrence and Exploitation. - Oxford: Pergamon Press, 1990.

4. Jaber, J. O., Probert, S. D., Williams, P.T. Evaluation of oil yield from Jordanian oil shales // Energy. 1999. Vol. 24, No. 9. P. 761-781. 
5. Smadi, M., Haddad, R. The use of oil shale in Portland cement concrete// Cement Concr. Compos. 2003. Vol. 25, No. 1. P. 43-50.

6. Al-Otoom, A. Utilization of oil shale in the production of Portland clinker // Cement Concr. Compos. 2006. Vol. 28, No. 11. P. 3-11.

7. Lea, F. The Chemistry of Cement and Concrete. - London: Edward Arnold Ltd, 1970.

8. Bale, C. W., Pelton, A. D., Thompson, W. T. Facility for the Analysis of Chemical Thermodynamics (FACT). - Montreal, Canada: Ecole Polytechnique, 2000 (http://www.crct.polymtl.ca).

9. Jak, E.Predictions of coal ash fusion temperatures with FACT thermodynamic package // Fuel. 2002. Vol. 81, No. 13. P. 1655-1668.

10. Al-Harahsheh, A., Al-Otoom, A., Shawabkeh, R. Sulfur distribution in the oil fractions obtained by thermal cracking of Jordanian El-Lajjun oil Shale // Energy. 2005. Vol. 30, No. 15. P. 2784-2795.

11. Robie, R, Hemingway, B, Fisher, J. Thermodynamic properties of minerals and related substances at $298.15 \mathrm{~K}$ and 1 bar $\left(10^{5}\right.$ Pascals $)$ pressure and at higher temperatures. - Washington: US Government Printing Office, 1978.

12. Peray, K. E. Cement Manufacturers Handbook. - New York: Chemical Publishing Company, 1979.

13. Thoenen, T., Kulik, D. Nagra/PSI Chemical Thermodynamic Data Base 01/01 for the GEM-Selektor (V.2-PSI) Geochemical Modeling Code: Release 28-02-03. PSI Technical Report TM-44-03-04 about the GEMS version of Nagra/PSI chemical thermodynamic database 01/01. 2003.

Presented by J. Purga

Received January 22, 2008 